\title{
The effect of a.c. and d.c. electric field on the dielectric properties of $\mathrm{Na}_{0.5} \mathrm{Bi}_{0.5} \mathrm{TiO}_{3}$ ceramic
}

\author{
J.Suchanicz \\ Institute of Physics and Computer Science, Pedagogical University, \\ 2 Podchorążych Str., 30-084 Kraków, Poland
}

Received August 31, 1998

The dielectric properties were studied for $\mathrm{Na}_{0.5} \mathrm{Bi}_{0.5} \mathrm{TiO}_{3}$ ceramic as a function of a.c. electric field, d.c. electric field, frequency, and temperature. The increasing strength of a.c. electric field shifts the electric permittivity function towards lower temperatures. However, d.c. electric field reduces electric permittivity and slightly suppresses the frequency dispersion. These effects can be connected with the existence in NBT of polar regions.

Key words: ferroelectric, NBT

PACS: 77.22.-d, 77.22.Ch, 77.84.Dy

\section{Introduction}

Sodium-bismuth titanate $\mathrm{Na}_{0.5} \mathrm{Bi}_{0.5} \mathrm{TiO}_{3}$ (NBT) has a perovskite type structure and possesses two structural phase transitions: cubic to tetragonal $\left(540-520{ }^{\circ} \mathrm{C}\right)$ and tetragonal to rhombohedral (in a wide temperature range where both phases coexist). The tetragonal phase seems to be ferroelastic [1] and rhombohedral phase is ferroelectric. The maximum of electric permittivity occurs at about $\mathrm{T}_{\max } \approx 320{ }^{\circ} \mathrm{C}$. Simultaneously no changes in domain structure, crystal structure, specific heat etc. are observed at this temperature. Some studies suggested that this maximum is connected with the antiferroelectric phase transition [2-3]. However the majority of investigation data deny this suggestion. Some experimental results indicate the coexistence of both phases (tetragonal and rhombohedral) in a wide temperature range including $\mathrm{T}_{\max }$. It follows, from neutron scattering investigations that already at high temperatures the unstable polar regions arise [4]. Their correlation radius increases with the decrease of temperature while below the temperature of $280{ }^{\circ} \mathrm{C}$ these regions are stable. They act as the nucleation centers of the ferroelectric phase, which occur approximately below $200{ }^{\circ} \mathrm{C}$. Taking into account the neutron scattering and other results of the investigations, the anomalies of some quantities, which appear in the vicinity of $320^{\circ} \mathrm{C}$, should be associated with relaxation processes which 


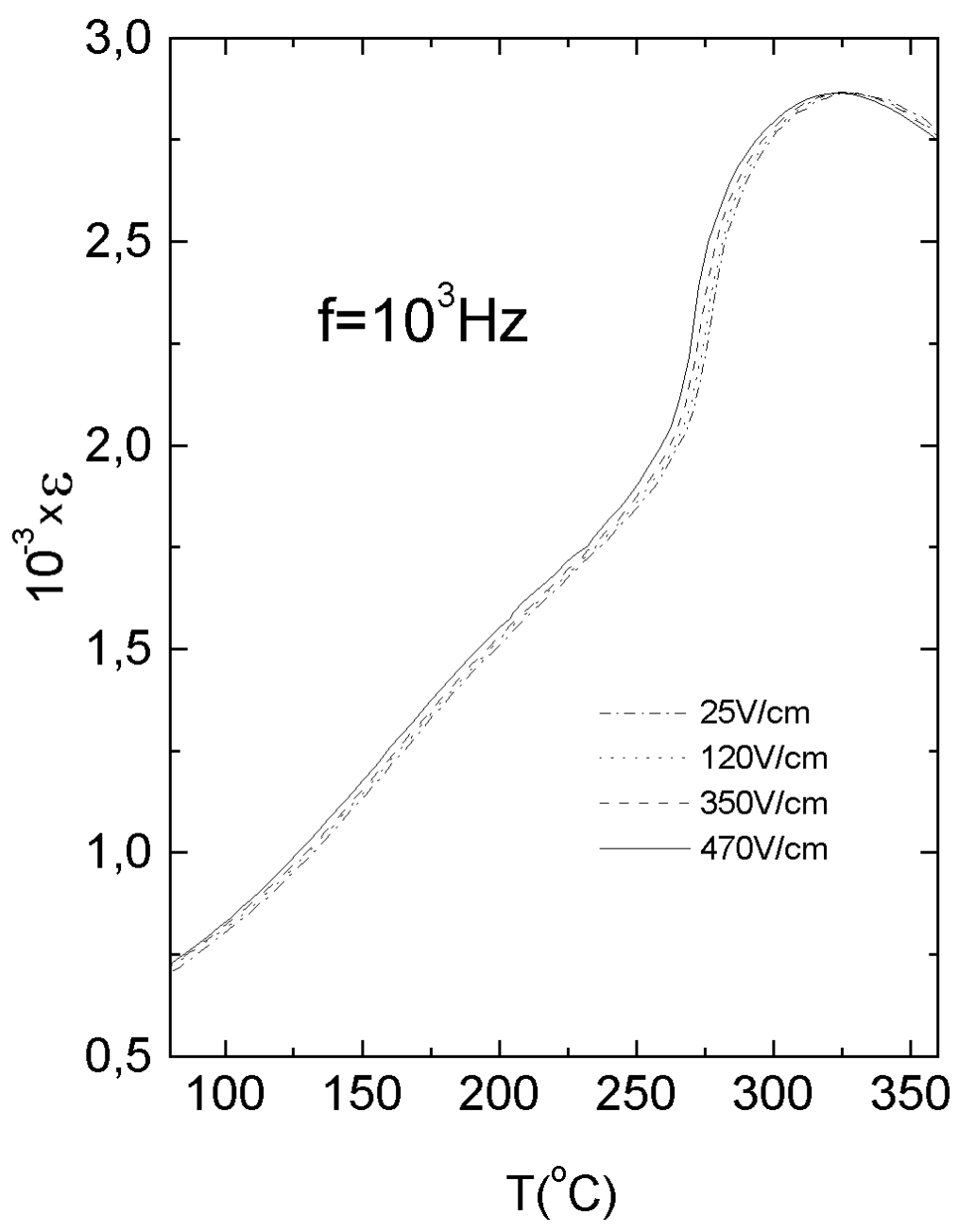

Figure 1. Temperature evolution of the electric permittivity of NBT ceramic at different amplitudes of a.c.electric field.

originate from electromechanical interacting between polar regions and nonpolar matrix [5-6].

In order to understand the dynamics of polar regions the effect of a.c. and d.c. electric field on dielectric properties of NBT ceramic is presented in the present paper.

\section{Experimental method}

The NBT ceramic have been sintered by a solid state reaction described in [7]. The temperature measured by thermocouple in touch with the sample was stabilized exactly to $0.1{ }^{\circ} \mathrm{C}$. Prior to the measurements the sample was maintained at $570{ }^{\circ} \mathrm{C}$ during 0.5 hours. Measurements were carried out for silver or gold electroded samples using a HP4284A LCR meter. Capacity C and dielectric losses tan $\delta$ were recorded directly from the meter. The a.c. and d.c. field dependence experiments 
were performed in the temperature range from 20 to $380{ }^{\circ} \mathrm{C}$ over the frequency range $20 \mathrm{~Hz}$ to $100 \mathrm{kHz}$ on heating runs with the rate $1.5^{\circ} \mathrm{C}$. The strength of the a.c. and d.c. electric field changed from $3 \mathrm{~V} / \mathrm{cm}$ up to $470 \mathrm{~V} / \mathrm{cm}$ and from 0 up to $2 \mathrm{kV} / \mathrm{cm}$, respectively. At d.c. field dependence, the measuring a.c. field was $3 \mathrm{~V} / \mathrm{cm}$.

\section{Results}

The increasing strength of a.c. electric field shifts the electric permittivity characteristic towards lower temperatures (figure 1). However the effect of a.c. electric field on the maximum value of electric permittivity and on the temperature of its occurrence is negligible. D.c. electric field reduces electric permittivity in the temperature range from room up to about $280^{\circ} \mathrm{C}$ and slightly suppresses the frequency dispersion (especially below the temperature about $200{ }^{\circ} \mathrm{C}$, recognised as the temperature point to the ferroelectric phase) (figures 2 and 3 ). At the temperature of about $280{ }^{\circ} \mathrm{C}$ the d.c. effect is negligible. The d.c.-biasing also reduces the permittivity maximum $\left(\epsilon_{\max }\right)$ (especially at higher frequencies) (figure 3 ). However, the effect of d.c. field on temperature of permittivity maximum $\left(\mathrm{T}_{\max }\right)$ is negligible. Also, the dielectric losses were reduced and showed more clear maximum around $200{ }^{\circ} \mathrm{C}$ connected with the appearance of the low-temperature ferroelectric state (figure 4). D.c. dependence on dielectric losses is negligible about $T_{\max }$. The other effect of the d.c.-biasing is the range of the bump on electric permittivity connected with the ferroelectric phase formation occurrence, which expands several degrees toward higher temperatures (figure 3). The similar results were obtained for NBT ceramic under the applied axial pressure [8]. The considered shift in the electric permittivity under d.c.-biasing is not possible to calculate due to the diffusion character of these anomalies.

\section{Discussion and conclusions}

The effect of a.c. electric field on electric permittivity of NBT is different from that for relaxor PMN [9-10]. For PMN this effect takes place below $\mathrm{T}_{\max }$ and is much stronger than in NBT. For NBT however this effect takes place in the whole temperature range and can be explained as a shift of $\epsilon(\mathrm{T})$-function towards lower temperatures. This behaviour of electric permittivity under a.c.-biasing can be the result of specific coupling of mechanical stresses induced by the electrostrictive effect and elastic properties of polar regions [6]. As it has been mentioned in the introduction, the correlation radius of dynamically existing polar regions grows as the temperature decreases and below about $280{ }^{\circ} \mathrm{C}$ these polar regions become stable. The results of d.c.-biasing also point out this temperature as the characteristic one. The increasing strength of d.c. electric field leads to the decrease of electric permittivity and dielectric losses in the range from room temperature up to about $280{ }^{\circ} \mathrm{C}$. As the temperature increases the d.c. dependence of electric permittivity becomes weaker and at the temperature of about $280{ }^{\circ} \mathrm{C}$ it is negligible. The ordering action of d.c.electric field promotes the increase of polar regions and their junction to greater 


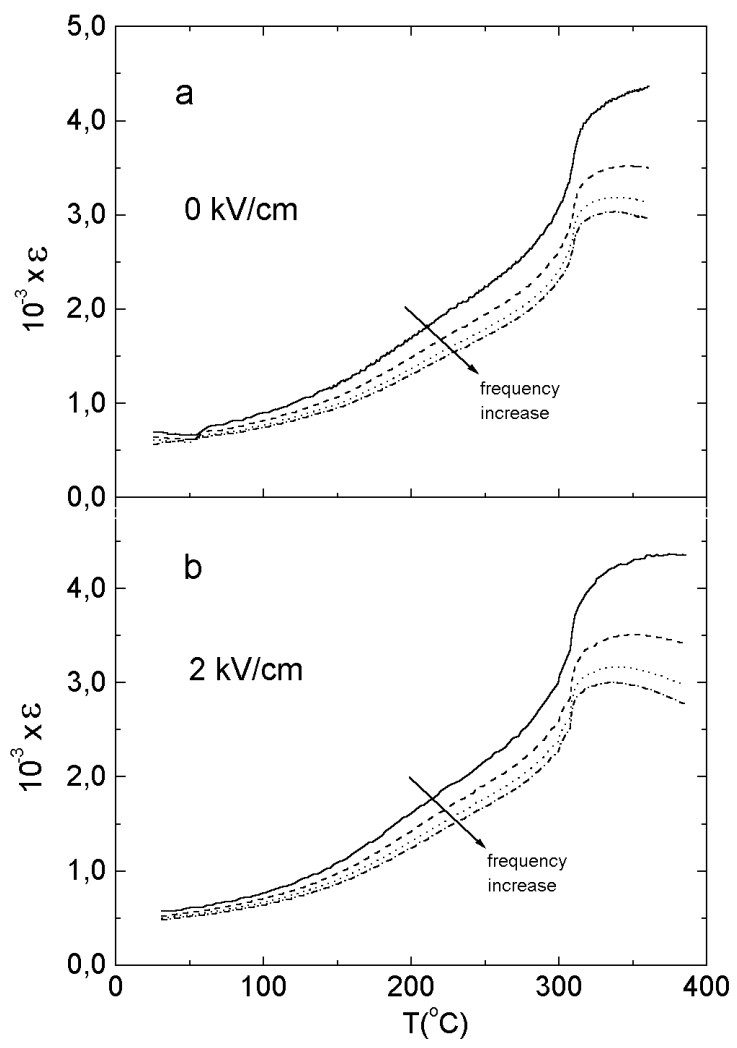

Figure 2. Temperature evolution of the electric permittivity of NBT ceramic with the measuring frequencies of $0.2,1,4$, and $10 \mathrm{kHz}$ without (a) and with (b) d.c. electric field.

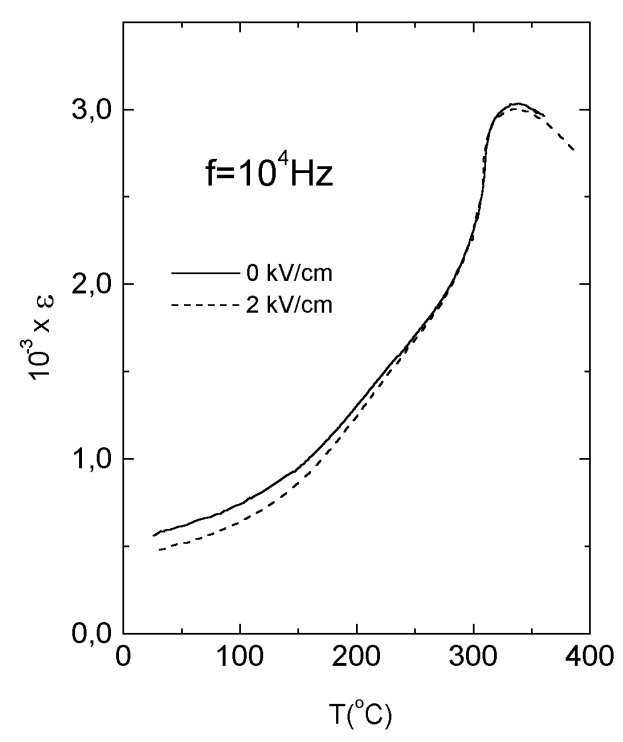

Figure 3. Temperature evolution of the electric permittivity of NBT ceramic.

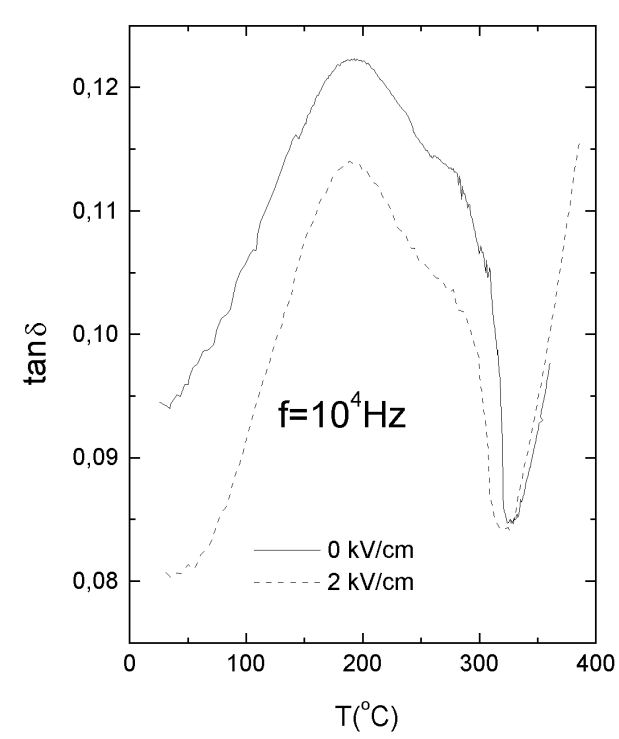

Figure 4. Temperature evolution of the dielectric losses of NBT ceramic. 
complexes (especially at lower temperatures). The dielectric response $(\delta \mathrm{P} / \delta \mathrm{E})$ of the objects of this type is weaker (electric permittivity is reduced). Simultaneously the distribution of relaxation times is narrowing (contribution from relaxation processes shifts itself to lower frequencies), which can lead to the observed suppressing of frequency dispersion. As the temperature increases the results of the d.c.-biasing become weaker, considering the decrease both of size of polar regions and its correlation radius. At the temperature of about $280{ }^{\circ} \mathrm{C}$, where the polar regions are no more stable, the effect of d.c.-biasing is negligible. However, at temperatures around $\mathrm{T}_{\max }$ relaxation phenomena can be connected with reorientation of unstable polar regions and their wall motions. Using the d.c.electric field makes these processes more difficult, which can lead to the observed reducing of the electric permittivity in this temperature range. Because the maximum of electric permittivity in NBT takes place at a comparatively high temperature $\left(\mathrm{T}_{\max } \approx 320{ }^{\circ} \mathrm{C}\right)$, the contribution of ionic polarization (especially at lower frequencies) should be expected. However for the sample used in the present measurements for temperatures around $\mathrm{T}_{\max }$ the dielectric losses are small (figure 4), which can be the evidence of good quality of the ceramics.

\section{References}

1. Isupov V.A., Kruzina T.V. Same physical properties of $\mathrm{Na}_{0.5} \mathrm{Bi}_{0.5} \mathrm{TiO}_{3}$ ferroelectric. // Izv. Akad. Nauk SSSR, Series of Physics, 1983, vol. 47, p. 616.

2. Sakata K., Masuda Y. Ferroelectric and antiferroelectric properties of $\left(\mathrm{Na}_{0.5} \mathrm{Bi}_{0.5}\right) \mathrm{TiO}_{3}-\mathrm{SrTiO}_{3}$ solid solution ceramics. // Ferroelectrics, 1974, vol. 7, p. 347.

3. Isupov V.A., Pronin I.P., Kruzina T.V. Temperatura dependence of birefringence and opalescence of the sodium-bismuth titanate crystals. // Ferroelectrics Letters, 1984, vol. 2, p. 205.

4. Vakhrushev S.B., Isupov V.A., Kvyatkovsky B.E., Okuneva N.M., Pronin I.P., Smolensky G.A., Syrnikov P.P. Phase trasition and soft modes in the sodium-bismuth titanate. // Ferroelectrics, 1985, vol. 63, p. 153.

5. Suchanicz J., Roleder K., Kwapulinski J., Jankowska-Sumara I. Dielectric and structural relaxation phenomena in $\mathrm{Na}_{0.5} \mathrm{Bi}_{0.5} \mathrm{TiO}_{3}$ single crystals. // Phase Transitions, 1996, vol. 57, p. 173.

6. Suchanicz J. Behaviour of $\mathrm{Na}_{0.5} \mathrm{Bi}_{0.5} \mathrm{TiO}_{3}$ ceramics in the a.c. electric field. // Ferroelectrics, 1998 (to be published).

7. Smolensky G.A., Isupov V.A., Agranovskaya A.J., Krainik N.N. New ferroelectrics of complete composition. // Fiz. Tv. Tela, 1960, vol. 11, p. 2982.

8. Molak A., Suchanicz J. Electric properties of ceramics $\mathrm{Na}_{0.5} \mathrm{Bi}_{0.5} \mathrm{TiO}_{3}$ under axial pressure. // Ferroelectrics, 1996, vol. 189, p. 53.

9. Glazounov A.E., Tagantsev A.K., Bell A.J. Effect of the electric field on the dielectric permittivity of lead magnesium niobate relaxor. // Ferroelectrics, 1996 vol. 184, p. 217.

10. Tsurumi T., Soejima K., Kamiya T., Daimon M. Mechanism of diffuse phase transition in relaxor ferroelectrics. // Jpn. J. Appl. Phys., 1994, vol. 33, p. 1959. 


\section{Вплив постійного і змінного електричного поля на діелектричні властивості кераміки $\mathrm{Na}_{0.5} \mathrm{Bi}_{0.5} \mathrm{TiO}_{3}$}

\section{Я.Суханіч}

Інститут фізики та обчислювальної техніки, Педагогічний університет,

Польща, 30-084 Краків, вул. Подхоронжих, 1

Отримано 31 серпня 1998 р.

Досліджено діелектричні властивості кераміки $\mathrm{Na}_{0.5} \mathrm{Bi}_{0.5} \mathrm{TiO}_{3}$ як функції змінного і постійного електричного поля та температури. Збільшення змінного електричного поля зсуває діелектричну проникність в область нижчих температур, а постійне електричне поле зменшує проникність і дещо придушує її частотну дисперсію. Ці ефекти можуть бути пов'язані з існуванням в НВТ полярних областей.

Ключові слова: сегнетоелектрик, НBT

PACS: 77.22. $-d$, 77.22.Ch, 77.84.Dy 